\title{
InSAR observations of the 1993-95 Bering Glacier (Alaska, U.S.A.) surge and a surge hypothesis
}

\author{
Dennis R. FATLAND, ${ }^{1}$ Craig S. LinGLE ${ }^{2}$ \\ ${ }^{1}$ Vexcel Corporation, Boulder, Colorado 80301-3242, U.S.A. \\ E-mail:fatland@vexcel.com \\ ${ }^{2}$ Geophysical Institute, University of Alaska Fairbanks, Fairbanks, Alaska 99775-7320, U.S.A.
}

\begin{abstract}
Time-varying accelerations were observed on Bagley Icefield during the 1993-95 surge of Bering Glacier, Alaska, U.S.A., using repeat-pass synthetic aperture radar interferometry. Observations were from datasets acquired during winter 1991/92 (pre-surge), winter 1993/94 (during the surge) and winter 1995/96 (post-surge). The surge is shown to have extended $110 \mathrm{~km}$ up the icefield from Bering Glacier to within $15 \mathrm{~km}$ or less of the flow divide. Acceleration and step-like velocity profiles are strongly associated with an along-glacier series of central phase bull's-eyes with diameters of $0.5-4 \mathrm{~km}$. These bull's-eyes are interpreted to represent glacier surface rise/fall events of $\sim 3-30 \mathrm{~cm}$ during 1-3 day observation intervals and indicate possible migrating pockets of subglacial water. We present a surge hypothesis that relates late-summer climate to englacial water storage and thence to the subglacial water dynamics - pressurization, hydraulic jacking, depressurization and migration - suggested by our observations.
\end{abstract}

\section{INTRODUCTION}

Bering Glacier, together with Bagley Icefield, its associated accumulation area, and smaller tributaries, covers an area of $\sim 5200 \mathrm{~km}^{2}$ in the Chugach-Saint Elias Mountains of southcentral Alaska, U.S.A. In spring 1993 a major surge began on the Bering Glacier ablation area which proceeded in two phases through summer 1995, both ending with outburst floods at the terminus. An overview of the Bagley Icefield/Bering Glacier system and the progression of the surge is given in Fatland and Lingle (1998). While that work devoted particular attention to the dynamics of the West Bagley Icefield, this study presents results from a subsequent analysis of the surge of the considerably larger Bagley Icefield proper, located further east (Fig. 1). Further observations and studies of the 1993-95 Bering Glacier surge can be found in Lingle and others (1993), Molnia (1993), Molnia and Post (1995), Muller and Fleischer (1995), Roush (1996) and Herzfeld and Mayer (1997).

Surging glaciers have been recognized for several centuries, but serious scientific study of the problem of how and where surges happen began only as recently as the 1960s. A major symposium on the subject was held in Quebec, Canada, in 1968, where Hoinkes (1969) showed that periodic catastrophic glacier advances were recorded in 1678 and 1772. Research into this phenomenon over the last three decades has focused on the complex relationship between surges and subglacial hydrology. Robin and Weertman (1973) described the backward propagation of surge motion up-glacier from the initiation or "trigger" zone, hypothesizing that this was due to the damming of subglacial water. Subsequent theoretical work by Bindschadler (1983) described a parameterized relationship between subglacial water pressure and glacier surging. Important detailed studies of glacier surges were presented by Kamb and others (1985), Kamb (1987) and Raymond (1987). Surge cessation was observed to coincide with floods of sediment-laden water at the glacier terminus on Variegated and West Fork Glaciers, Alaska (Harrison and others, 1986, 1994). This work demonstrated that large-scale disruption of the basal drainage system results in large volumes of subglacially stored water and bed separation during surges. The resultant high subglacial water pressure is thought to cause rapid surge motion through some combination of ice-bed decoupling (i.e. flotation and sliding of the ice over a hard bed) and/or shear failure of non-consolidated material at the base of the glacier (i.e. plastic failure of a deformable, soft bed (Truffer and others, 2000)). The work presented here makes use of high-resolution space-borne radar data to contribute to the analysis of this complex problem.

Bagley Icefield and the upper part of Bering Glacier were observed from winter 1991/92 through winter 1995/96 by European Space Agency (ESA) synthetic aperture radars (SARs) on board European Remote-sensing Satellites 1 and 2 (ERS-1 and -2 ) in short repeats (1 and 3 days). This relatively brief revisit interval is well suited to analyzing temperate glaciers using SAR interferometry (InSAR). Data downlinked to the Alaska SAR Facility from these satellites were interferometrically processed into three datasets showing the nature of ice flow on Bagley Icefield before, during and after the surge. The first dataset, acquired in winter 1991/92 by ERS-1 (3 day repeat orbit), shows the quiescent pre-surge surface velocity field on most of Bagley Icefield, which is the primary accumulation area of Bering Glacier. The second dataset, acquired by ERS-1 (3 day repeat orbits) during winter 1993/ 94 , is a time series of 15 interferometric images showing the surface velocity field and surface acceleration over 2 months on Bagley Icefield during the dominant first stage of the surge, slightly less than 1 year after the probable time of onset. The third dataset, acquired by ERS-1 and -2 during tandem 1 day repeat period, winter 1995/96, shows the return to quies- 


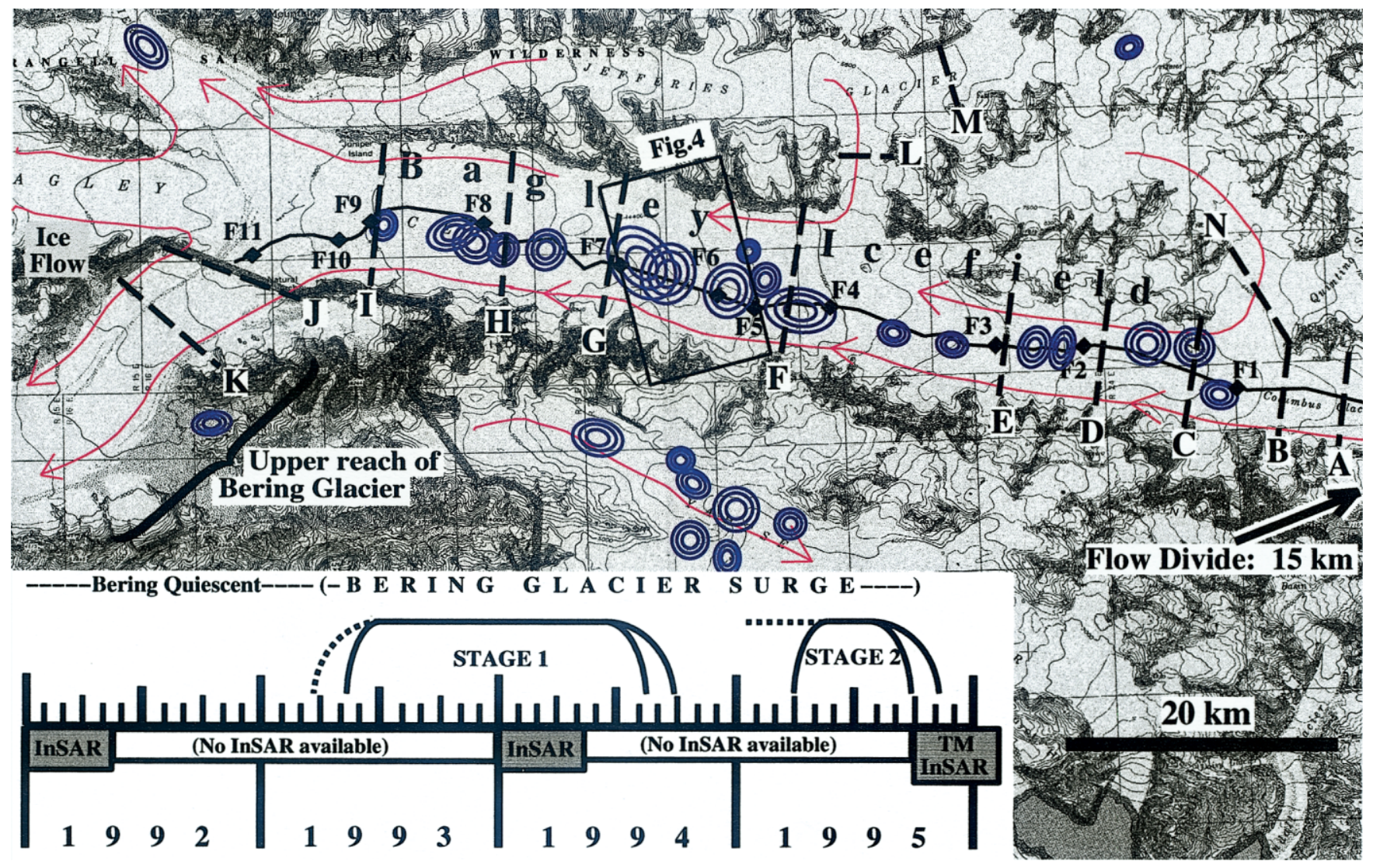

Fig. 1. Bagley Icefield (from the U.S. Geological Survey 1:250 000 Bering Glacier topographic map). The central longitudinal profile line begins $\sim 15 \mathrm{~km}$ west of the flow divide and runs west $100 \mathrm{~km}$ to Bering Glacier. Phase bull's-eyes apparent in the 1994 time sequence (January-February) are marked by concentric circles. The timeline inset shows the progression of the Bering Glacier surge above the horizontal bar and ERS observation phases below the bar. ERS-1 InSAR data were obtained from 3 day repeat orbit periods before and during the surge ("InSAR" labels). ERS-1/-2 1 day repeat tandem mission (TM) data were acquired after the surge in late 1995 ("TM InSAR" label).

cence both on Bagley Icefield and along the entire Bering Glacier ablation area to the terminus, after the surge.

An important feature of the present study is the discovery and interpretation of consistently recurring anomalies in the data which are referred to as "phase bull's-eyes". These anomalies may be indicative of moving pockets of trapped subglacial water.

\section{METHODS}

The use of SAR interferometry for glacier measurements and generalized surface deformation has been described elsewhere (e.g. Goldstein and others, 1993; Joughin, 1995; Rignot and others, 1995, 1996; Joughin and others 1996a,b,c, 1998, 1999; Kwok and Fahnestock, 1996; Rignot, 1996; Fatland and Lingle, 1998; Alsdorf and Smith, 1999; Reeh and others, 1999). The basic technique is a comparison of two co-registered SAR images, both of which have phase angle values assigned to each pixel. By subtracting these phases on a pixel-by-pixel basis, a new image is generated called an interferogram in which (under good conditions) the stationary random component of the phase is cancelled, leaving a residual signal containing information about the surface topography and surface motion. The surface topography phase arises from the slightly different orbital paths - separated by a "baseline" of a few hundred meters or less - followed by the SAR platform during the two source data acquisitions. On glaciers this topographic phase signal typically resolves vertical relief with a resolution on the order of $20 \mathrm{~m}$. The surface-motion signal is due to small relative displacements of the moving ice on the scale of the radar carrier wavelength, in this case $5.7 \mathrm{~cm}$ for ERS-1/-2, along the radar line of sight.

The surface-motion phase signal, typically an order of magnitude larger than the surface topography phase signal, can be separated from the latter using multiple differencing of more than one interferogram in circumstances where the surface is moving at a constant velocity. This technique and other technical details of SAR interferometry are further described in the references cited above. In this work, the differentiation of these two phase signals using multiple differencing techniques was not feasible due to the constantly changing surface velocities on Bagley Icefield during the surge (ice acceleration). Instead, surface motion was obtained for small-baseline pairs by first performing two-dimensional phase unwrapping and then extracting one-dimensional transect datasets, either laterally across the glacier or longitudinally along the glacier center line. The topographic signal was ignored along the lateral transects, which traverse a region with very little vertical relief. Along the glacier center line, which has a modest and fairly constant slope, the effect of the phase signal due to surface topography was approximately compensated using an estimate of the orbital separation (interferometric baseline). This approach isolates the surface-motion phase signal and yields Bagley Icefield surface velocities before and during the surge.

Figure 1 shows Bagley Icefield and associated tributaries, with glacier flow directions indicated by red arrows. Two transect datasets are indicated: a series of lateral transects 


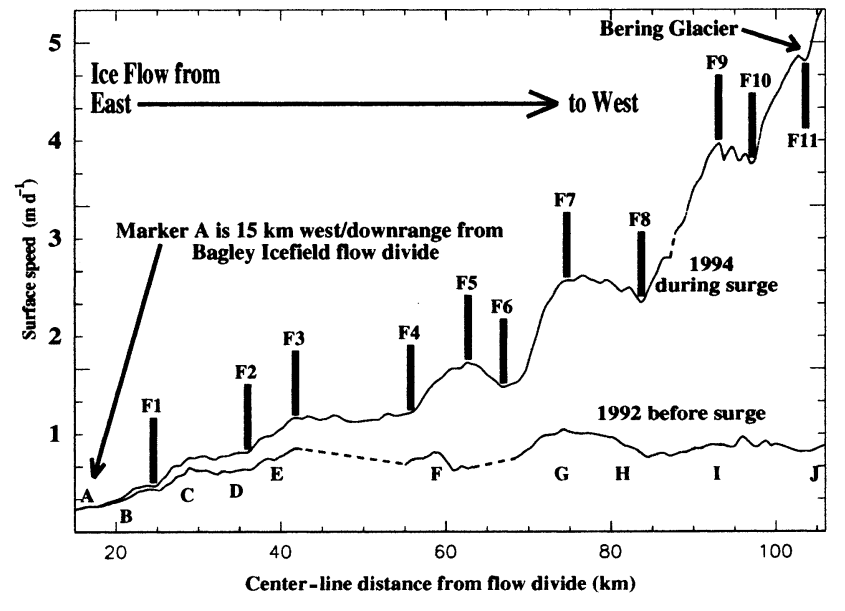

Fig. 2. Bagley Icefield comparison of 1992 to 1994 longitudinal velocity profiles. Center-line markers F1-F11 and transects A- 7 correspond to locations marked in Figure 1. Areas with signal loss are interpolated with dotted lines.

and a longitudinal profile. The lateral transects are labeled $\mathrm{A}-\mathrm{N}$; transects $\mathrm{A}-\mathrm{K}$ follow the course of Bagley Icefield, and transects $\mathrm{L}-\mathrm{N}$ traverse tributary glaciers. The longitudinal profile is indicated by the dark center line passing through markers F1-F1l, with slight meandering to track the coherent signal of the fastest-moving ice.

As described, transect data were extracted from interferograms and converted directly to velocity profiles, ignoring elevation. The main 1993-94 (during-surge) data sequence consisted of normal interferometric baselines of 98, 54, 19, 4, 30, 139 and $63 \mathrm{~m}$. Assuming a worst-case transverse elevation variation across the glacier as large as $200 \mathrm{~m}$, this would result in corresponding velocity errors of 5, 3, 1, 0.2, 2, 7 and $3 \mathrm{~cm} \mathrm{~d}^{-1}$. A worst-case linear-tilt error in baseline estimation would contribute errors to the estimated velocity on the order of $5 \mathrm{~cm} \mathrm{~d}^{-1}$. These errors are comparable to other errors in velocity estimation resulting from assumptions about flow direction and are much smaller than the typical center-line velocities of about $300 \mathrm{~cm} \mathrm{~d}^{-1}$ (Fig. 2).

For the longitudinal transect (points Fl-Fll in Fig. 1), the gross elevation signal was subtracted from the data prior to conversion to surface motion. This signal arises from the $880 \mathrm{~m}$ elevation difference between the transect starting point, $15 \mathrm{~km}$ down-glacier from Bagley Icefield flow divide, and the end point, another $90 \mathrm{~km}$ down-glacier at the Bagley/West Bagley confluence. In each case, the baselinedependent topographic signal was subtracted linearly, introducing self-consistent small-order errors due to neglect of actual variations in the glacier surface slope. Note that phase bull's-eyes, which are interferogram anomalies discussed in detail below, also introduce surface-velocity errors of comparable magnitude on a scale of $1-4 \mathrm{~km}$. The velocity errors introduced by these approximations are estimated to be generally $<20 \mathrm{~cm} \mathrm{~d}^{-1}$.

The phase of a pixel in a surface-motion interferogram represents a fractional-wavelength relative shift in radial distance from the SAR location (at some moment in its trajectory) to the surface. This radial distance is only one of the three components of the true ice-velocity vector (see Fatland and Lingle, 1998). The remaining two components of the velocity vector may be derived by several means, including a priori knowledge of how glaciers flow through valleys. Since SAR interferometry provides only part of the icevelocity solution, there is some ambiguity or "room for interpretation", particularly in accounting for anomalous signals in the data. In the ensuing discussion we interpret just such an anomalous signal as vertical motion of the ice, rather than the more conventional idea of motion in the plane of the glacier surface. There is nothing in the interferometric data prohibiting such an interpretation, hence it remains only to supply a supporting argument. This argument will be based on both the nature of the data and the current picture of glacier hydrology.

\section{PRE-SURGE TO SURGE-STATE VELOGITY GHANGE}

\section{Observations}

Figure 2 shows center-line velocity along the longitudinal profile F1-Fll (Fig. 1) for 19-22 January 1992, before surge onset, and 11-14 January 1994, during the surge. The sequence of transect locations $\mathrm{A}-\mathrm{J}$ are also indicated in Figure 2 for reference. The first evidence of the 1993-95 Bering Glacier surge appeared in an ERS-1 SAR image acquired in April 1993 (Lingle and others, 1994). The Bering Glacier surge was first directly observed during spring 1993 in the ablation area below Bagley Icefield (Lingle and others, 1993, 1994; Molnia, 1993; Roush, 1996). The surge subsequently propagated down-glacier to the terminus and up-glacier toward the Bagley Icefield flow divide. This is apparent in the during-surge 1994 longitudinal velocity profile of Figure 2, which shows higher velocities and more variability compared to the presurge profile. On West Bagley Icefield the surge-state velocity was very close to 2.7 times the pre-surge velocity (Fatland and Lingle, 1998). On Bagley Icefield the correspondence is not as precise, but the velocity profiles before and during the surge share a degree of similar structure.

Profile segments with longitudinally increasing velocity along the upper reach of Bagley Icefield - west of marker F1, between markers F2 and F3, and between markers F4 and F5 - all occur directly downstream from tributary confluences. Along the lower reach of Bagley Icefield from F6 to F10 there is relatively little confluence of ice (only contributions from embayments in the confining valley walls), but the profile segments of increasing velocity - from $\mathrm{F} 6$ to $\mathrm{F} 7$, and from $\mathrm{F} 8$ to $\mathrm{F} 9$ - are more pronounced. The sharpest velocity increase occurs at the confluence of Bagley Icefield and West Bagley between F10 and F11. Interferogram phase bull's-eyes occur more frequently in this downstream region.

\section{Interpretation}

The velocity profiles in the upper reach of Bagley Icefield (transect A through marker F4) are similar in structure. This contrasts with the strong 92 vs 94 velocity divergence further west (downstream), showing that the surge influence increases with proximity to Bering Glacier. In the upper reach of Bagley Icefield, the surge-state velocity profile retains the expression of local modulating influences. In fact, the velocity profile suggests a correlation between the locations of tributary confluences and extensional flow, which is in agreement with theoretical and observational results (Gudmundsson, 1997; Gudmundsson and others, 1997).

The region between markers $\mathrm{F} 4$ and F6 shows a transition to much stronger surge influence, followed by more pronounced, step-like velocity increases from F6 through F10 in the 1994 profile, through a reach with comparatively little tributary input. Finally, as the east and west branches 
of Bagley Icefield flow together into Bering Glacier, the segment between F10 and F11 exhibits the strongest velocity increase with longitudinal distance. Here the velocity reaches $5 \mathrm{~m} \mathrm{~d}^{-1}$, still less than half the maximum velocities observed by Roush (1996) farther downstream on Bering Glacier. In general, the step-like nature of the velocity profile strongly suggests localized phenomena modulating the surge speed of Bagley Icefield.

\section{SHEAR MARGIN WIDTHS AND MAXIMUM PRINGIPAL STRAIN RATES}

The Bagley Icefield shear-margin widths and maximum strain rates are presented in Figure 3 as a means of characterizing the ice deformation at a small number of sites.

\section{Observations}

Figure 3 shows a comparison of 1992 and 1994 shear margin widths and maximum principal strain rates across both the northern and southern shear margins of Bagley Icefield (sites A-K, Fig. 1). Herein "shear margin width" is defined as the lateral extent of the transition zone of shearing glacier ice from the static outer edge to the central-flow ice mass. Thus there are two such widths per lateral glacier transect, a left and a right, typically comprising $20-40 \%$ of the total glacier width. Also included are data for the three transects from tributaries, labeled L, M and N. The widths of the shear margins were estimated from interferograms. In some cases, this estimation was interpolated across bands of incoherent interferogram phase, where the incoherence is due to some combination of surface deformation and limitations of the SAR resolution. The interpolative jump across incoherent signal on the glacier shear margins is accomplished by moving in a circuitous path through the image, starting from the static ice at the glacier's edge and going upstream to regions of better signal. From there a continuous path is traced across the shear margin and finally back down to the moving ice at the transect of interest. (While source image correlation vectors can be used to approximately determine the speed change across a shear margin gap, circuitous routes (when possible) give much better solutions.) Maximum extensile strain rates in the range $1-7 \times 10^{-4} \mathrm{~d}^{-1}$ were estimated from the steepest lateral velocity gradients, assuming flow parallel to the valley walls. This gives a principal extensive strain-rate axis oriented $45^{\circ}$ down-glacier from the valley walls relative to the transverse direction, causing corresponding shear crevasses to point $45^{\circ}$ up-glacier, inward from the valley walls.

\section{Interpretation}

The primary down-glacier trends shown in Figure 3 are the decrease in shear margin width and increase in shear strain rates at markers $\mathrm{F}-\mathrm{I}$. That is, the data show that as Bagley Icefield accelerates during the surge, the shear margins narrow. The tributary sites $\mathrm{M}$ and $\mathrm{N}$ appear to be essentially unaffected by the surge, with only changes in the width of one shear margin for each. In contrast, tributary site L, which is in closer proximity to the down-glacier region of Bagley Icefield, shows a decrease in shear-margin strain rate during the surge and a $500 \mathrm{~m}$ shift in the location of the central flow channel relative to 1992. This may be due to a dynamic restraint imposed on the tributary by the surge.

We presume, as stated above, that during the surge the basal shear stress is reduced. Narrowed shear margins imply that there is a reduction in lateral support from the valley walls as well. The corresponding changes we anticipate are an increase in speed (as observed) and a potential shift of ice-mass support to longitudinal stress.

\section{PHASE BULL'S-EYES}

\section{Observations}

Before proceeding to further observations of Bagley Icefield during the surge, it is relevant to establish the common occurrence of phase bull's-eyes in interferograms of glaciers, as shown for example in Figures 1 and 4. This phenomenon is elaborated in further detail below in the Discussion section.

Phase bull's-eyes are radially symmetric phase patterns with varying degrees of elongation and/or distortion. They occur both in isolation as well as in conjunction with other bull's-eyes, and are consistently located over the deeper parts of a channel of ice. Phase bull's-eyes are typically $0.5-$ $4 \mathrm{~km}$ in diameter and, due to their size and magnitude, cannot represent topography. Consequently phase bull's-eyes on glaciers must necessarily be due to a component of ice motion along the one-dimensional SAR line-of-sight vector to the ice surface. This motion, herein referred to as a "bull'seye event", must take place during the 1-3 day observation interval between two SAR imaging passes. Bull's-eye events are therefore time- and space-localized variations in the typical movement of the glacier surface. Figure 1 indicates a distribution of bull's-eye events from the 1994 surge data, in which bull's-eyes are apparent on Bagley Icefield, the non-surging Yahtse Glacier to the south, and elsewhere.

Phase bull's-eyes occur in image data with both positive and negative curvature (bumps and dips). Because they have typical magnitudes of one to five fringes, they are often obscured by the interferogram phase of the normal downstream flow of the glacier, typically consisting of dozens of fringes in convoluted patterns reflecting margin shearing and other spatial variations in glacier speed and direction. The more subtle bull's-eye phase fringes become apparent in differential interferograms in which two ice-flow phase signals are used to cancel one another (see Fig. 4). Suppose for example that one has data for two consecutive time intervals $\mathrm{A}$ and $\mathrm{B}$ with corresponding interferograms $\alpha$ and $\beta$. Further suppose that a bull's-eye event occurs during either interval A or B but not both. Because of the complexity of the interferogram phase signal due to the glacier motion, the phase bull'seye is not clearly apparent in either $\alpha$ or $\beta$. However, the differential interferogram $(\alpha-\beta)$ will remove most of the surface-motion phase to reveal the phase bull's-eye on the glacier. In this case, the time at which the bull's-eye event occurred is still ambiguous. For example, negative phase curvature in the differential interferogram $(\alpha-\beta)$ will represent either a "toward the radar" motion during interval A, or "away from the radar" motion during interval B at the bull'seye. This ambiguity can be resolved using a third observation interval C (interferogram $\gamma$ ). If the bull's-eye event occurred during time $\mathrm{A}$, then this event will also be apparent in differential interferogram $(\alpha-\gamma)$ but not in $(\beta-\gamma)$.

\section{Interpretation}

Without independent information, the interpretation of phase bull's-eyes must rely on a conceptual transition from indicated motion along the radar line of sight — implicit in 


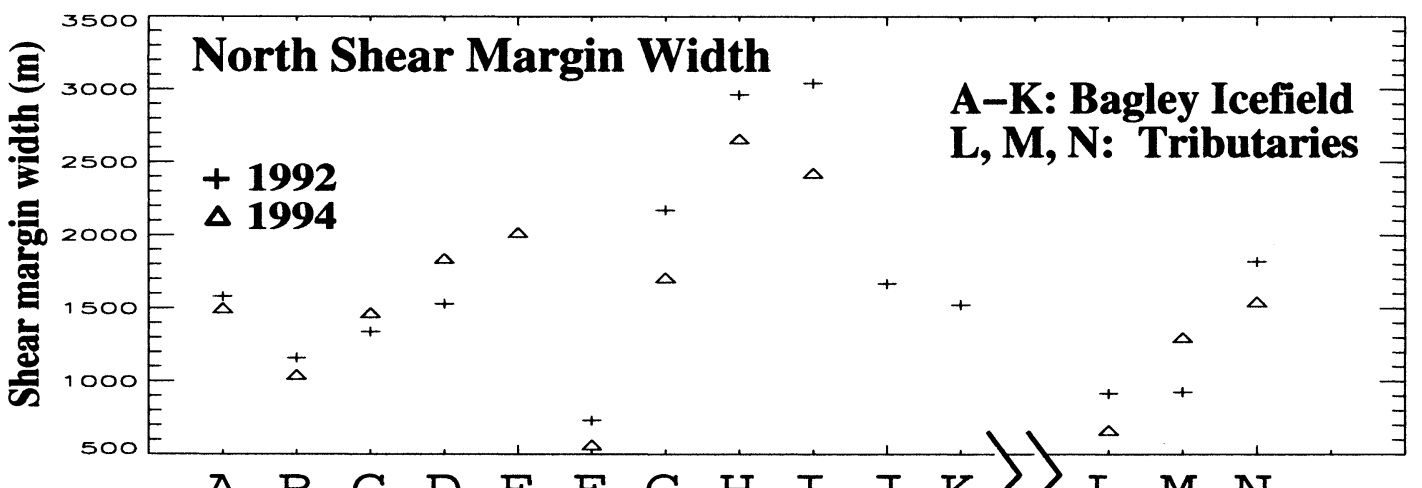

A B C C D E F G

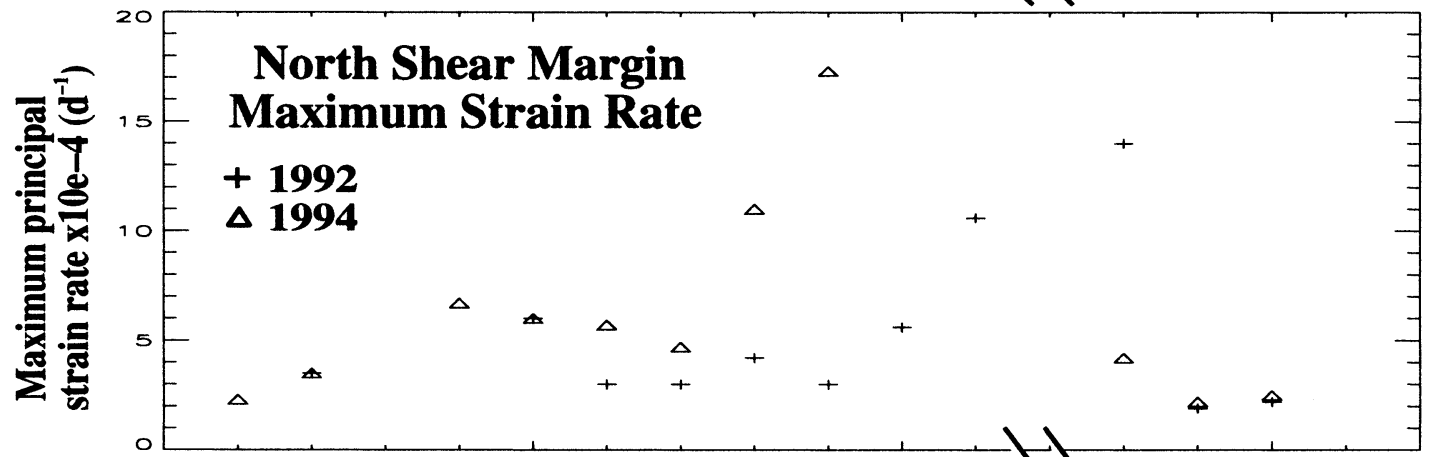

A B C C D E $F$
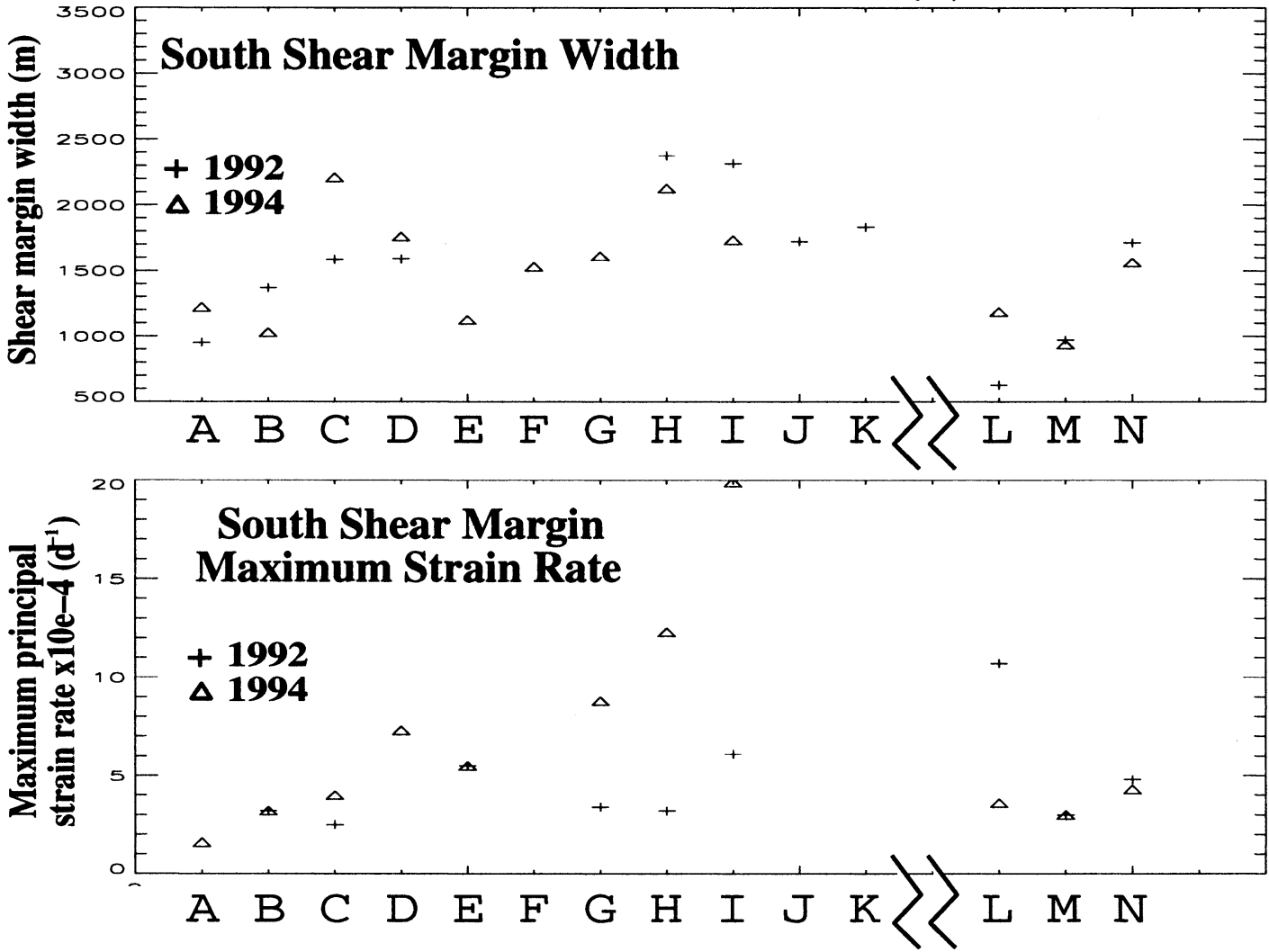

Fig. 3. Lateral transect sites: widths and strain rates, 1992 vs 1994. The horizontal axes are observation site indices, labeled at the bottom by letters $A-\mathcal{N}$ corresponding to the transects shown in Figure 1. Missing data are due to poor signal quality. Across most shear margins the velocity transect shows a "steepest gradient" region of linear velocity increase which was used to calculate maximum principal strain rates (parallel flow in two dimensions assumed, after Vaughan (1993)). The shear-margin width error is estimated at $100 \mathrm{~m}$ ( a subjective observation). Strain-rate error is estimated at $2 \times 10^{-4} d^{-1}$.

the image data - to actual motion of the glacier surface in three dimensions. A simple idea invokes vertical rise or fall of the surface and is adopted here for a hypothetical model of the principal mode of bull's-eye events. In this model, subglacial water flows through a distributed subglacial drainage system to the deep central part of the glacier channel, creating a localized transient increase in basal water pres- sure that exceeds the overburden pressure. Such localized transients, also thought to occur during surge onset, would lift the glacier upwards from the bed, resulting in the observed phase bull's-eyes. Similarly when subglacial conditions permit water drainage or dispersion from a locally elevated region, the surface would drop, producing a phase bull's-eye of opposite sign. 


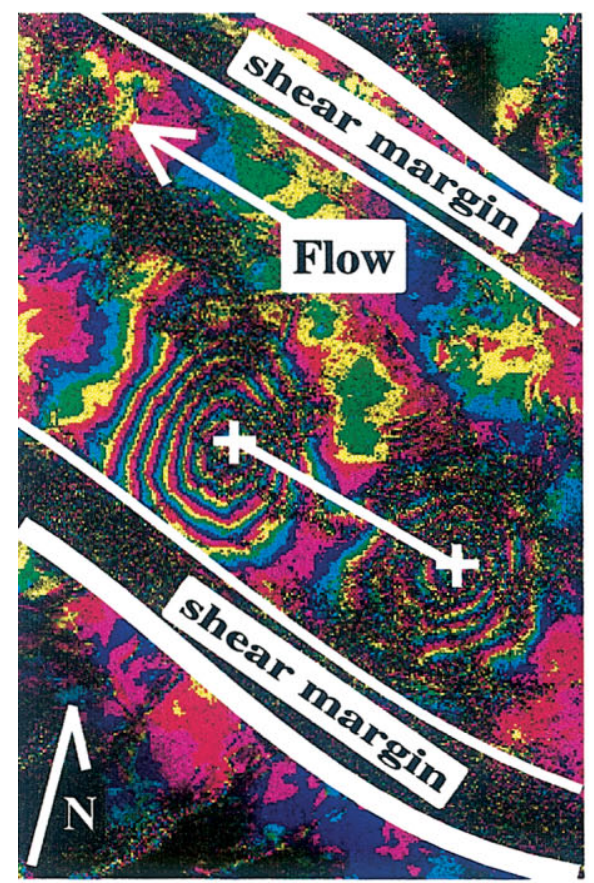

(a) 1994, Jan (2-5) - Jan (11-14)

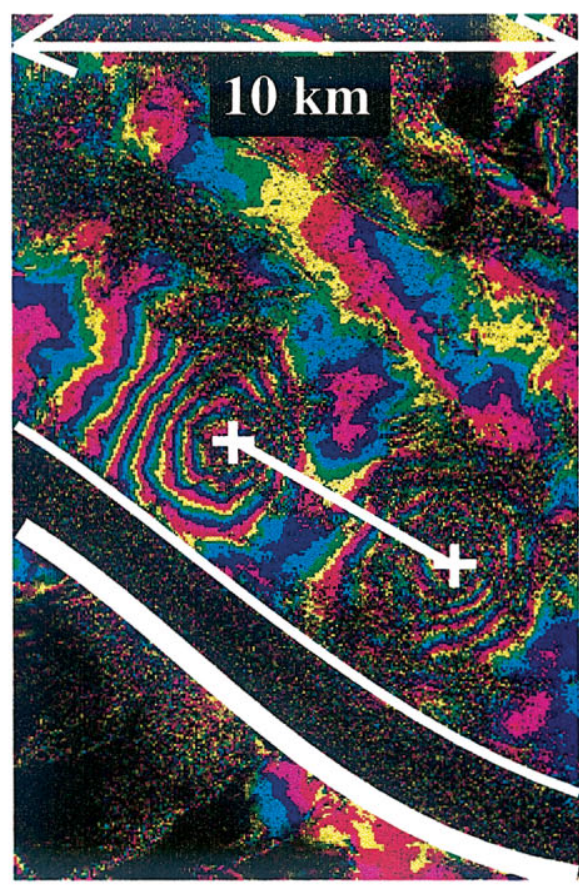

(b) 1994, Jan (2-5) - Jan (17-20)

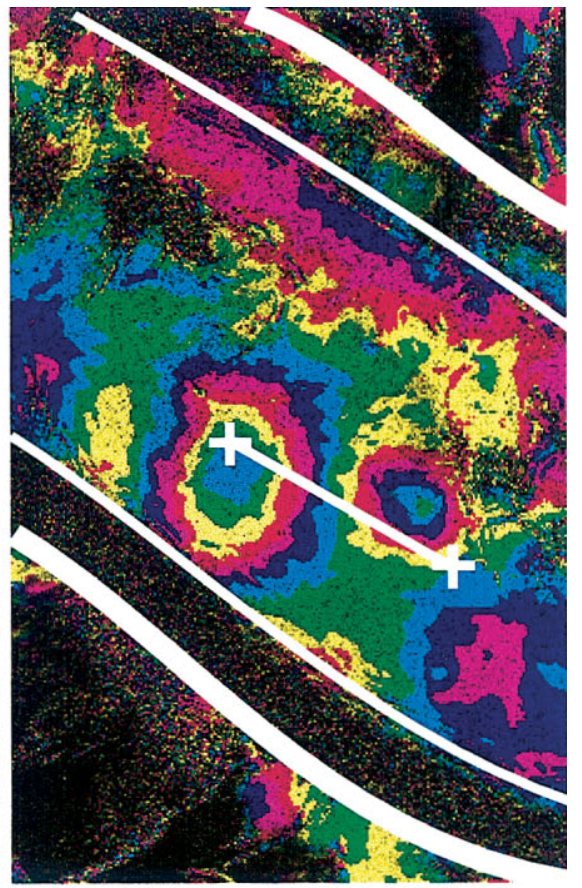

(c) 1994, Jan (11-14) - Jan (17-20)

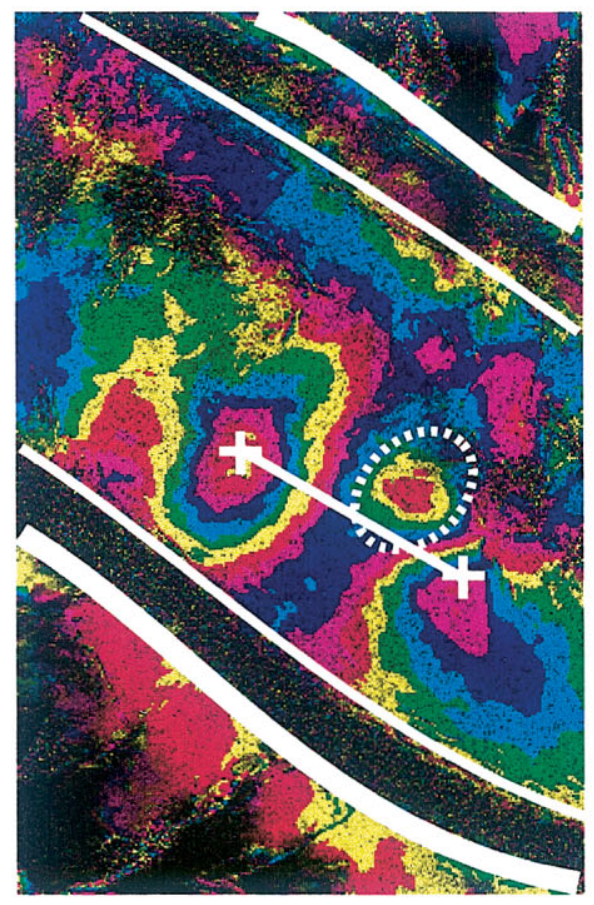

(d) 1994, Jan (11-14) - Jan (20-23)

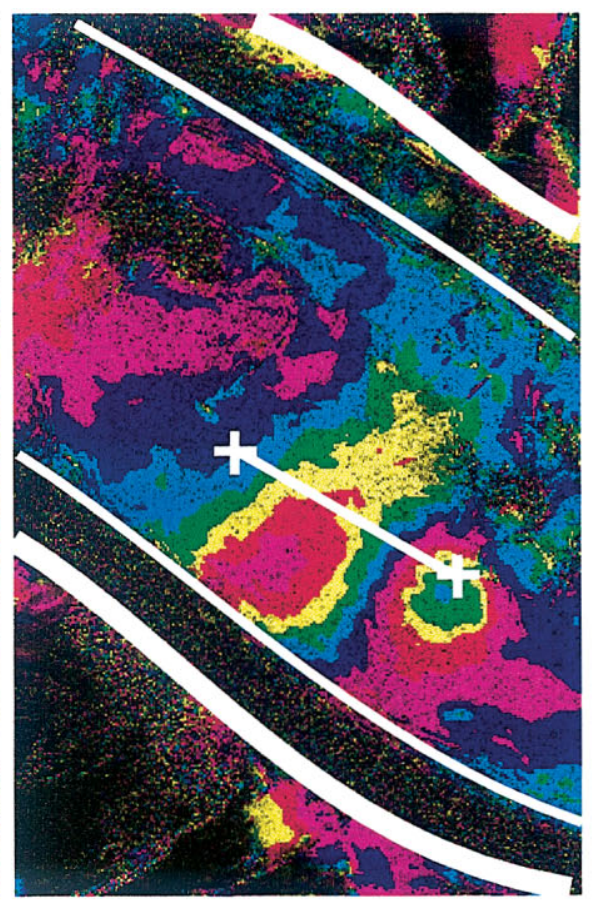

(e) 1994, Jan (17-20) - Jan (20-23)

Fig. 4. Multiple differential interferogram time sequence. Three differential interferograms $(a-c)$ resolve the time ambiguity of the two adjacent bull's-eye events seen in $(a)$ and ( $b$ ). Both must occur during either the 2-5 January or the 11-14 January interval (a). Since the bull's-eyes are not visible in the 11-14 January to 17-20 January comparison (c), they must "belong" to the 2-5 January interval. Each fringe represents $3 \mathrm{~cm}$ uplift, for a total of $\sim 24 \mathrm{~cm}$ at the bull's-eye centers. (c-e) also show smaller-scale events at slightly different locations. The dashed white circle in $(d)$ indicates a region probably active during both 2-5 January and 11-14 January but not 17-23 January.

Joughin and others (1996b) considered flow over bumps as a source of "bull's-eye" motion phase in Greenland. In that case, however, as the ice moves over the bumps the bull's-eyes appear as conjugate pairs. This is not the case for the temperate glacier bull's-eyes discussed here, which usually occur in isolation.

There are two other observations from the data that are supportive of the hypothesis that phase bull's-eye events are driven by liquid water. First, we note that glacier surface lakes have been observed to drain into subglacial conduit systems elsewhere (see, e.g., Nolan and Echelmeyer, 1999). In the 1994 Bering Glacier interferometric data a bull's-eye is seen on a Bering Glacier tributary ice embayment directly downstream from a surface lake (near marker K; Fig. 1). The second piece of supportive evidence is from data acquired several months after the surge ended (27-28 October 1995) that show the stagnant Bering Glacier terminus to be dotted with fourteen bull's-eyes. Eleven of these indicate surface subsidence from 3 to $30 \mathrm{~cm}$ during a 1 day time interval. This observation is consistent with the notion that after a surge ends, stored basal 
water drains out to the terminus through open channels. The aggregate change in water volume indicated by these terminus bull's-eyes is on the order of $10-30 \times 10^{6} \mathrm{~m}^{3} \mathrm{~d}^{-1}$ or a flow rate of several hundred $\mathrm{m}^{3} \mathrm{~s}^{-1}$. We suppose that this 1 day interferometric snapshot of the terminus bull's-eye field in October 1995 is characteristic of ongoing water drainage during the months after the surge ended.

Phase bull's-eyes are commonly distorted from circular shape in a manner that appears consistent with downstream ice flow, particularly around bends or at channel confluences. This suggests that the simple vertical motion model is only a starting point and that asymmetrical bull's-eye events may also indicate variations in horizontal velocity.

\section{DURING-SURGE AGGELERATION}

\section{Observations}

Seven sequential interferograms from 1994 were used to generate two different time sequences of center-line acceleration profiles (Fig. 5). An acceleration profile indicates how the glacier accelerates along its length during the surge. The source interferogram intervals were: 2-5 January, 11-14 January, 17-20 January, 20-23 January, 7-10 February, 13-16 February and 25-28 February. The first time sequence is represented by plots $(\mathrm{a}-\mathrm{e})$ and (i), and the second sequence by plots $(b)$ and $(\mathrm{f}-\mathrm{h})$. The reference points $\mathrm{Fl}-\mathrm{F} 10$ in Figure $5 \mathrm{~b}$ correspond to those labeled on the center-line profile in Figure 1. Each source velocity profile was adjusted by the gross topographic gradient based on the interferometric baseline as described above. Velocity profile pairs were then subtracted and normalized by the inter-observation time interval to produce the sequence of longitudinal acceleration profiles, where the vertical axis represents acceleration in $\mathrm{md}^{-2}$ and the horizontal axis represents distance downglacier, west of the Bagley Icefield flow divide in $\mathrm{km}$.

The first time sequence (Fig. $5 \mathrm{a}^{-}$e and i) shows differences in consecutive time-interval velocity measurements. In plot (a) the dip/drop-out between markers F6 and F7 is due to the 2-5 January bull's-eye uplift event (Fig. 4). Other bull's-eye events also contribute localized bumps in the profiles, visible in plots (b) and (c).

The second time sequence (Fig. $5 \mathrm{~b}$ and $\mathrm{f}-\mathrm{h}$ ) shows acceleration profiles over progressively longer time intervals. Plot (b) has a time interval of 6 days, and as this interval increases up to 45 days in plot $(\mathrm{h})$, the small-scale structure in the acceleration profiles becomes less pronounced and a constant-slope acceleration profile emerges.

\section{Interpretation}

The plots in Figure 5 show several features of interest.

1. There is a long-term trend of gradually increasing acceleration with distance from the flow divide toward the Bering Glacier ablation area, at a slope of $\sim 2 \times 10^{-4}$ $\mathrm{cm} \mathrm{d}^{-2} \mathrm{~km}^{-1}$.

2. There are short time-interval acceleration changes along the lower reach of Bagley Icefield, down-glacier from approximately the $70 \mathrm{~km}$ location (between markers F6 and F7). This location, which corresponds to the two bull's-eyes shown in Figure 4, seems to behave like a hinge from which acceleration pulses emanate. This is particularly apparent in comparison of plots $(\mathrm{b}-\mathrm{e})$ and suggests a longitudinal characterization of Bagley Icefield in terms of upper, transition and lower regions.

3. There is a consistent positive acceleration value at the extreme eastward limit of the SAR scene (i.e. at $15 \mathrm{~km}$ downstream from the flow divide of Bagley Icefield, corresponding to the left edge of plots $(\mathrm{a}-\mathrm{i})$ ). This implies that the surge influence continues up to the flow divide, possibly displacing it eastward.

\section{AFTER-SURGE RETURN TO QUIESGENGE}

The first stage of the 1993-95 Bering Glacier surge ended in August 1994 with an outburst flood at the terminus, followed by about 9-10 months of quiescence (Roush, 1996). The second phase of the surge began in spring 1995 and ended in late summer. Later, on 27-28 October 1995, Bering Glacier was imaged twice by ERS-1/-2 in a 1 day repeat "tandem mission" orbit. The coherent phase signal for the Bering Glacier ablation area, from Bagley Icefield to the terminus on Vitus Lake near the Gulf of Alaska coast, is shown in Figures 6 and 7. With an interferometric baseline of $<20 \mathrm{~m}$ the contribution of topography to the phase of this single interferogram is negligible, so the detailed phase structure is attributed to surface motion.

Figure 6 shows the interferometric phase from the confluence of Bagley Icefield and West Bagley Icefield down Bering Glacier to the up-glacier limit of the terminus piedmont lobe. On Bagley Icefield at the eastern limit of the tandem SAR scene the post-surge velocity is about $45 \mathrm{~cm} \mathrm{~d}^{-1}$. This increases to a region of maximum velocity labeled in Figure 6 on the upper part of Bering Glacier that corresponds to the center of transect J in Figure 1. The post-surge velocity here varies from 100 to $130 \mathrm{~cm} \mathrm{~d}^{-1}$, which is comparable to the pre-surge velocity of $\sim 130 \mathrm{~cm} \mathrm{~d}^{-1}$ (Fig. 2). Downstream from site $\mathrm{J}$ there are three distinct regions where tightly spaced fringes indicate that the surface velocity is decreasing.

Further downstream on Bering Glacier the 1995 data show the ice flow essentially ceases about $40 \mathrm{~km}$ above the terminus, leaving the entire piedmont lobe stagnant but for a scattering of phase bull's-eyes (Fig. 7). The surface relief from the terminus on Vitus Lake to the eastern limit of the stagnant ice is about $700 \mathrm{~m}$ or about 1.4 phase fringes (very few). The bull'seye patterns observed across the piedmont lobe strongly suggest continued drainage of subglacial pockets of water resulting in localized subsidence, as discussed above.

\section{DISGUSSION: A HYPOTHETICAL PICTURE OF SURGE-TYPE GLACIERS}

We present a discussion of possible implications of phase bull's-eyes with regard to glacier hydrology, particularly glacier surges. It is possible that there are multiple glacier surge mechanisms; we refer herein to the surging mechanism specific to Bering Glacier and leave its degree of generality open to future work. With this in mind, our objective is to synthesize bull's-eye implications with other observations of surge-type glaciers in search of such a generalization.

The basic characteristics of the phase bull's-eyes can be summarized as follows:

1. Bull's-eyes are observed during winter. (These SAR mission parameters precluded InSAR observations during other seasons.) 


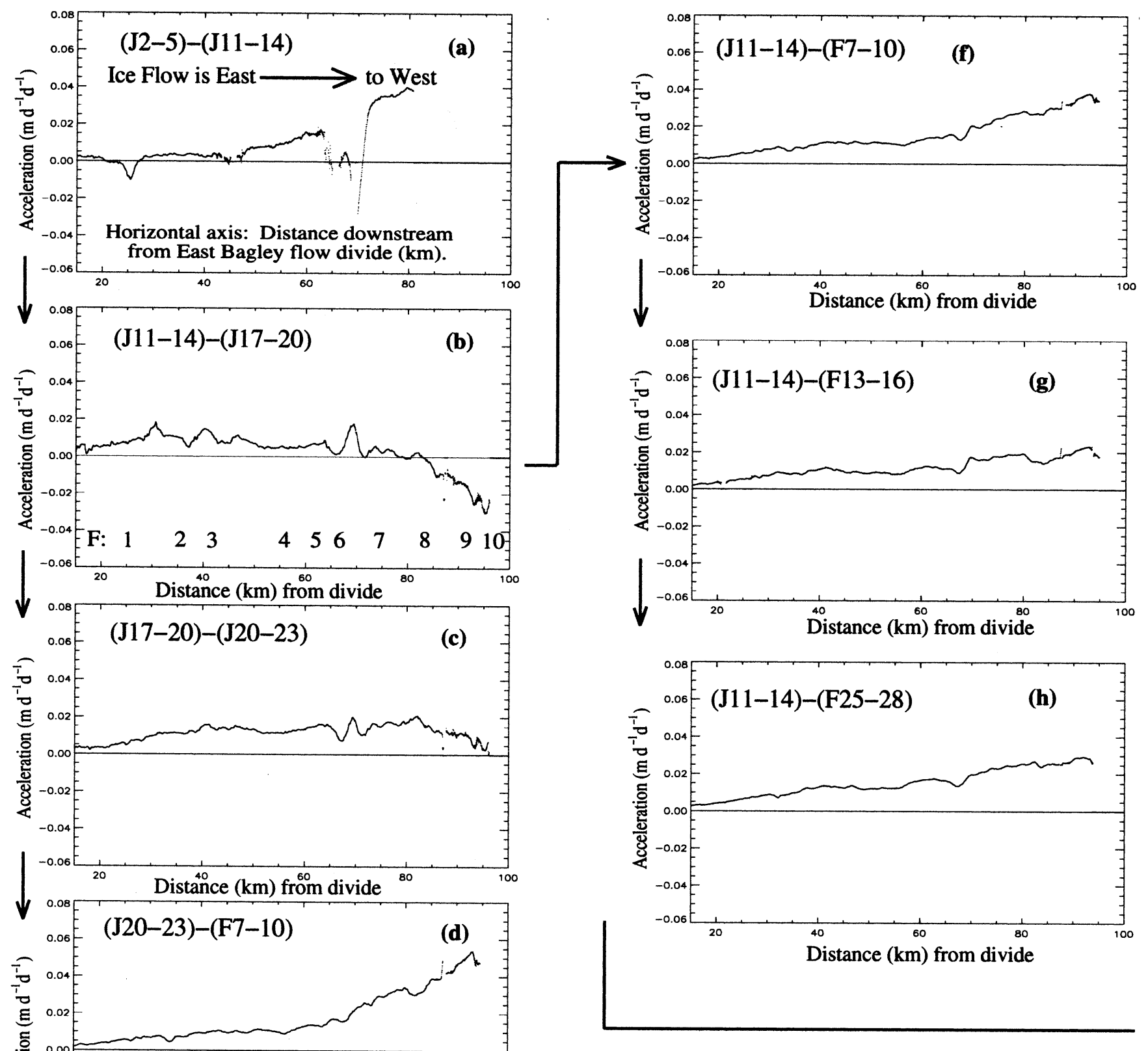

Fig. 5. Acceleration profile time sequence. The first time sequence $(a-e, i)$ shows sequential time-interval accelerations. The second sequence $(b, f-h)$ shows acceleration profiles over increasingly longer periods of time relative to the initial reference interval, 11-14 fanuary. Interval dates are indicated at the upper left, where $\mathcal{f}=$ Fanuary and $F=$ February (1994). For example, $(f)$ shows acceleration along the longitudinal center line between 11-14 January and 7-10 February. This acceleration increases with proximity to Bering Glacier (right extreme). 


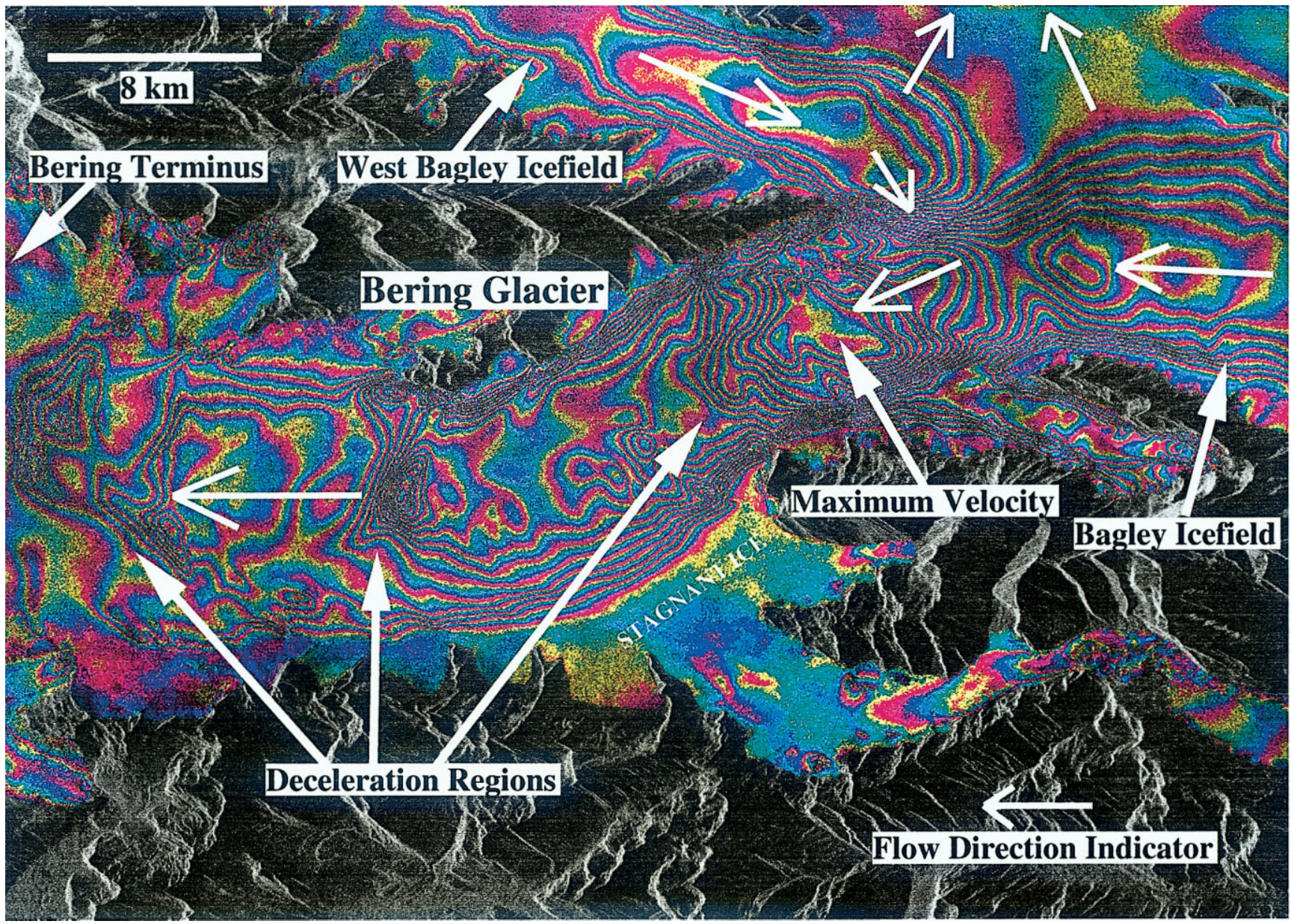

Fig. 6. Bering Glacier, 28 October 1995, after surge. TM interferogram of the reach of Bering Glacier from the Bagley Icefield confluence to the piedmont lobe, 27-28 October 1995. Surrounding mountains are rendered in grey scale to emphasize the moving glacier ice, in color. Arrows indicate flow direction.

2. Bull's-eyes indicate distinct events; ice is locally displaced on a scale of several $\mathrm{cm}$ relative to the normal glacier flow field.

3. In interpreting these bull's-eye displacements as primarily vertical motion (see inferences, below) they are evenly distributed between upward and downward displacement events.

4. Bull's-eyes typically cover roughly circular regions with an area of several $\mathrm{km}^{2}$.

5. Bull's-eyes are observed in these data only on glacier ice, i.e. they do not extend to confining valley walls or other bare ground.

6. Bull's-eyes are centered over thick ice, i.e. they are located at the central part of ice channels; tributaries, glaciers and icefields.

7. In one case, a bull's-eye is located directly down-glacier from a lake on the ice surface.

8. There is a notable exception to the equal distribution of upward and downward bull's-eye displacement events (item 3 above): the bull's-eyes apparent across the stagnant ice of the Bering Glacier terminus after the surge are predominantly downward displacements.

9. Bull's-eye events are observed over time-scales of 1-3 days. In the case where data are available from several consecutive 3 day intervals, a particular bull's-eye will tend not to persist from one such interval to the next, indicating that the associated event has a duration of $<3$ days.
10. Bull's-eye events commonly occur on non-surging glaciers, but occurred more frequently on Bagley Icefield while it was in surge.

We draw several inferences:

(1) The most compendious interpretation of the phase bull's-eyes is that they represent primarily vertical surface displacement, but not due to ice flowing over bumps (which would give persistently recurring bull's-eyes).

(2) These vertical displacements are due to emplacement or removal of water at the base of the glacier on time-scales of 1-3 days. We presume this water transport occurs via an active, semi-open subglacial drainage system. This idea is further elaborated below.

(3) Bull's-eyes therefore represent localized bed separation, regions where subglacial water pressure is in excess of the ice overburden pressure. We note that this phenomenon is considered intrinsic to glacier surge onset.

(4) Bull's-eyes do not describe the total subglacial water volume, only changes in that volume over 1-3 day timescales.

(5) Since the events we observe occur during winter and represent the flow of water down-glacier (a water sink), there might be a corresponding source supplying water to the glacier bed during winter. Discounting sliding friction and geothermal heating (insufficient to account for the observed volumes (Paterson, 1994)), we suggest the possibility of both horizontal (at the bed) and verti- 


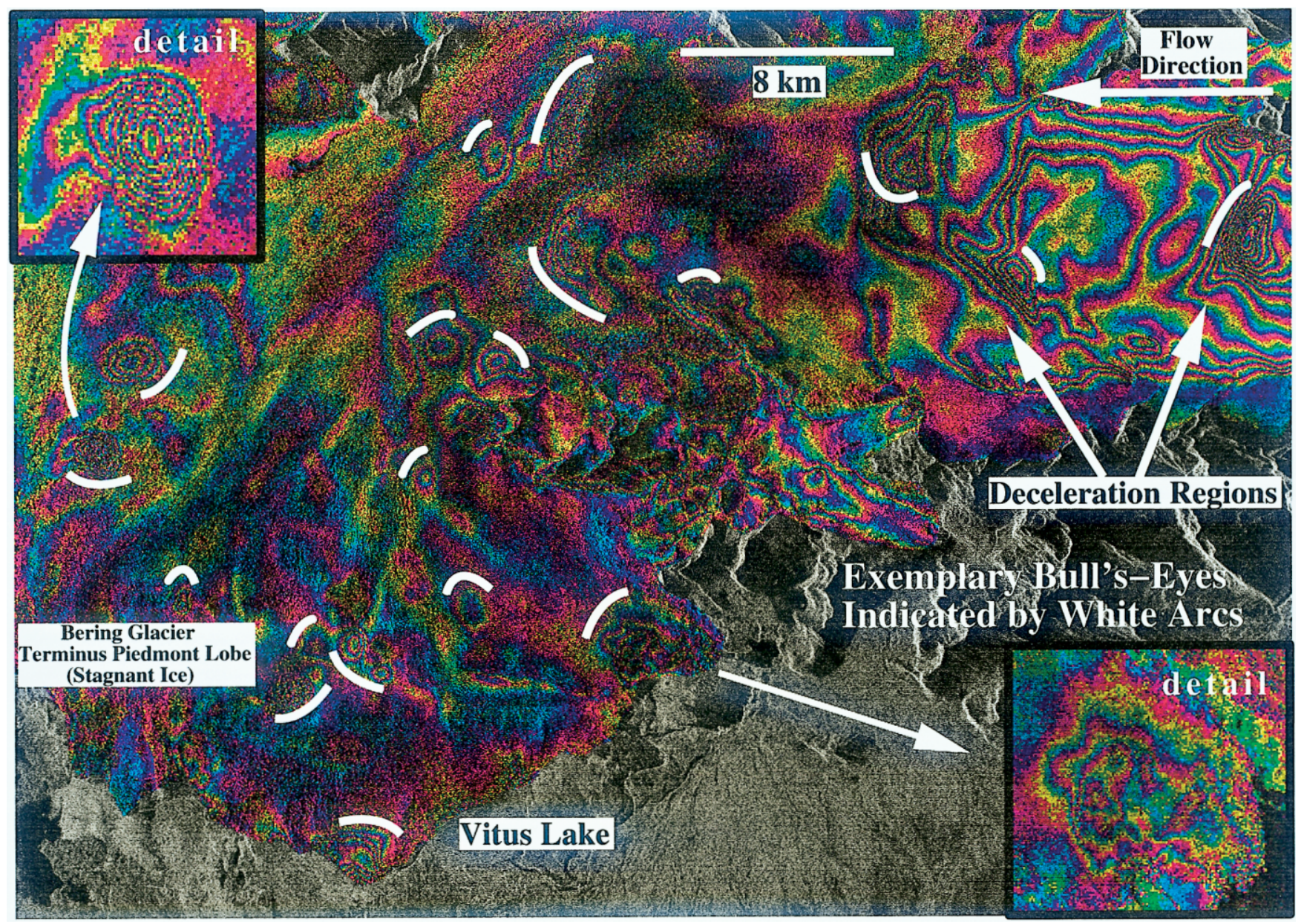

Fig. 7. Bering Glacier terminus, 28 October 1995, after surge. This image is a continuation of Figure 6 (overlap at upper right).

cal transport of englacially stored water available after the summer drainage system has shut down.

Two predictions can be made from this interpretation of the data: First, that under the right circumstances a pair of conjugate bull's-eyes could be found in InSAR glacier data: the upstream bull's-eye would show deflation as water drained out, and a downstream conjugate would show inflation. (So far, none have been observed in the data.) Second, glacier interferograms from data acquired in spring (with repeat observation intervals shortened to perhaps hours) should show very large bull's-eyes under appropriate conditions, in view of the high water flux at this time.

From these observations and inferences we proceed in two steps: first, we calculate relevant water volumes implied by the data and the literature; second, we present a hypothetical picture of the time evolution of a surge-type glacier over several decades.

\section{Water-volume estimates}

Figure 1 shows that 18 phase bull's-eyes were distributed over a reach of $\sim 70 \mathrm{~km}$ along the central flowline of the $10 \mathrm{~km}$ wide Bagley Icefield. These data are from seven interferograms collected over a 2 month observation interval, JanuaryFebruary 1994, during the Bering Glacier surge. The water volume implied by the dimensions of these bull's-eyes is on the order of several million $\mathrm{m}^{3}$ per bull's-eye (Fatland, 1998), emplaced or removed over a period of a few days. We infer that the bull's-eye water source is likely water flowing through a channel system at the base of the glacier. If such channels were to become blocked, the water could build up behind the obstruction until the hydrostatic pressure exceeded the overburden, lifting the glacier upwards a few $\mathrm{cm}$ at that point and producing a phase bull's-eye. If the channel were to open, the water could drain out, again on a time-scale of a few days, and the glacier surface would relax downward, producing a bull's-eye of opposite sign.

A second consideration in this water-transport picture is that of englacially stored water. The amount of water that could be stored englacially, considered as a uniform layer distributed across the basal area of the glacier, can be estimated from the existing literature. Fountain and Walder (1998) measured a maximum seasonal water storage of about $0.2 \mathrm{~m}$ per $\mathrm{m}^{2}$ of basal area at South Cascade Glacier, North Cascade Mountains, Washington, U.S.A. (see also Tangborn and others, 1975). Humphrey and Raymond (1994) found over $1 \mathrm{~m}$ of water per $\mathrm{m}^{2}$ of basal area was stored, much of it englacially, within Variegated Glacier during its 1982-83 surge. A rough estimate of Bagley Icefield water-storage capacity using temperate-glacier macroporosity measurements (Pohjola, 1994; Harper and Humphrey, 1995; Fountain and Walder, 1998) gives a layer of water 1$9 \mathrm{~m}$ thick since Bagley Icefield is considerably deeper than the previous two examples. In comparison, the bull's-eye data for January-February 1994 require a much smaller water layer of $\sim 4 \mathrm{~cm}$ per $\mathrm{m}^{2}$ basal area. Thus the bull's-eye water-layer depth is one to two orders of magnitude smaller than the estimated englacial storage potential.

The mid-winter time-frame of the data acquisitions implies that water input to the presumed semi-open subglacial conduit system does not originate from the glacier surface, arguing instead for englacially stored water moving vertically through the glacier. However, the localized nature of the bull's-eye events, both spatially and in time, raises the 
question of an appropriate mechanism for water influx from a (presumed) evenly distributed source. The resolution may reside in contingent conditions in the basal drainage network or in non-uniformities in englacial water storage as suggested by irregularly located crevasse fields and surface lakes on Bagley Icefield and other glaciers.

\section{Hypothetical time evolution of Bering Glacier}

The strong association in mid-winter of multiple bull's-eyes with the surging Bagley Icefield suggests a role in the surge process for englacially stored water. The question of how water becomes stored englacially in pores and cavities throughout the thickness of the glacier was addressed by Stenborg (1970) and later by Tangborn and others (1975) based on observations of South Cascade Glacier. They proposed that during late fall through early spring when ablation and rainfall are minimal, glaciostatic pressure tends to constrict and close meltwater passageways. This constricted drainage network results in the englacial storage of the input meltwater, at this time greatly reduced in volume. In the spring, melt onset causes a large vertical water influx and consequently a rapidly increasing hydrostatic head: the englacial and subglacial passageways are forced open, and stored water drains rapidly from the glacier. Using these ideas and those suggested by the phase bull's-eyes described above, we present a hypothetical picture of the time evolution over several decades of a surge-type glacier such as the Bagley IcefieldBering Glacier system.

(1) As the glacier thickens following a surge, a general hydrological pattern is repeated annually. First, water is stored englacially each autumn in the temperate ice. Some fraction of this water mass reaches the glacier bed, where it can move horizontally through the basal conduit system. During winter at certain sites, changes in basal water pressure may displace the glacier surface upwards or downwards, resulting in the phase bull's-eyes observed with SAR interferometry on non-surging glaciers (see, e.g., non-surging-glacier bull's-eye locations in Fig. 1). In spring, ablation onset drives additional water into the glacier. Increased downward drainage to the bed causes temporary speed-ups in spring and early summer (Iken and others, 1983; Iken and Bindschadler, 1986; Heinrichs and others, 1996; Nolan and Echelmeyer, 1999). This effect subsides as the glacier's summer drainage system is forced open, permitting discharge of water to the terminus.

(2) In the decades following a surge, this annual cycle repeats while the glacier steadily acquires mass, returning to its pre-surge geometry. Since glacier surges are quasi-periodic we suggest that the return to "pre-surge" ice thickness is a necessary but not a sufficient condition for the initiation of the next surge. It is possible that surge initiation is coupled to a stochastic aspect of the amount and distribution of the englacially stored water. We note that as the glacier grows during the inter-surge period, the englacial water-storage capacity increases.

(3) At the end of this inter-surge regrowth period, we imagine a surge-initiation scenario as follows: Suppose there passes a cool summer, accompanied by reduced ablation of surface water and ice. This results in early constriction of the basal drainage network and englacial storage of an abnormally large amount of surface meltwater. During the ensuing winter, gravity drives this water down to the bed without forcing open the basal drainage network. (The water emplaced at the bed at pressure would produce the many phase bull's-eyes seen on Bagley Icefield.) The surge is finally initiated when sufficient water has accumulated in subglacial storage to result in either extensive bed separation (a kind of zipper effect) or subglacial till shear failure.

Through this picture, we connect the commonly understood mechanisms for surge initiation with the evidence for basal hydraulic activity and vertical surface uplift provided by interferometric phase bull's-eyes. Here the time of year of surge initiation depends on the timing of the requisite englacial water storage. If this excess of water is stored during autumn, surge initiation could follow in the subsequent winter to early spring. The 1982-83 Variegated Glacier surge, for example, began in January 1982 (Kamb and others, 1985), and the first signs of the 1993-95 Bering Glacier surge were evident in late April 1993 (Lingle and others, 1994; Roush, 1996). The 1987-88 surge of West Fork Glacier in the Alaska Range, interior Alaska, may have begun as early as the latter part of August (Harrison and others, 1994), a time of year noted for little or no surface melt.

In summary, this view of the surge process bears on three aspects of glacier surge behavior. First, it suggests an explanation for the observation of Clarke and others (1984) that "long" glaciers have a statistically higher probability of being surge-type than "short" glaciers: since long glaciers tend to have lower average surface slope, they tend to be thicker and hence have more englacial water-storage capacity. Second, this stochastic picture accounts for the quasiperiodicity of surges. Third, it suggests an explanation for the observed winter-to-early-spring surge onset times: the gradual settling of englacial water to the bed during this part of the year could provide the hydrostatic pressure necessary for bed separation/till failure without forcing open the basal drainage system.

\section{Comparison with previous work on surge-type glaciers}

In the above text we have given a mechanical interpretation of InSAR phase bull's-eyes on temperate glaciers, as volume changes in pockets of subglacial water. We have also attempted to tie this phenomenon to surge initiation using an englacial water-storage hypothesis that couples seasonal climate to the obstruction of the subglacial drainage network. Here we summarize other work on surge-type glaciers, both with general remarks and by noting previous study of Variegated Glacier.

It is unknown at this time whether the Bagley-Bering system is underlain by bedrock or by a layer of glacial till. The latter has been found under the surge-type Black Rapids Glacier in the central Alaska Range, leaving open the question of surge motion either as plastic shear stress failure or as ice sliding over its bed. Concerning the subglacial drainage network, surge-type glaciers may be underlain by a superposition of "slow" and "fast" drainage systems. These systems are thought to be composed of a network of conduits and cavities, the latter possibly acting as storage bladders. Subglacial water pressure has been observed to be erratic in summer but high and steady in winter, typically at or above the overburden pressure. While this "near-flotation" condition is clearly relevant, basal sliding is thought to couple 
more directly with basal water volume. This idea is consistent with the higher preponderance of phase bull's-eyes on (surging) Bagley Icefield, relative to the fewer bull's-eyes on other non-surging glaciers (Fig. 1).

The most studied glacier surge to date is the 1982-83 surge of Variegated Glacier in the Saint Elias Mountains of south-central Alaska (Kamb and others, 1985). Although much smaller than Bering Glacier, Variegated Glacier is located in the same coastal climatic regime, about $150 \mathrm{~km}$ east-southeast of Bagley Icefield, and has a comparable surge period, about 20 years. Surge mechanisms involving failure of the glacier's internal plumbing and transformation of the subglacial water system at surge onset were described by Kamb (1987) and Raymond (1987).

Prior to its 1982-83 surge, water was found to be discharging rapidly and efficiently from Variegated Glacier via a central conduit excised up into the ice (see Röthlisberger, 1972). In contrast, the surge was marked by increased subglacial storage of water, slow discharge and high subglacial water pressure (Humphrey and Raymond, 1994). Thus analysis of surge-triggering has focused on a mechanism that would collapse a presumed pre-surge tunnel system, causing the subglacial water to spread out across the breadth of the glacier. Kamb (1987) and Raymond (1987) outlined comparable mechanisms for such surge initiation, for example from Raymond: "In winter a low steady-state discharge with little surface input can give high [pressure within the tunnels]. In this case, tunnels must collapse by a reinforcing feedback loop of decreasing discharge and rising water pressure once the [bed] separation condition is reached and water leaks from the tunnels ... This hypothesis indicates once a tunnel exists in the summer, its stability at high discharge and low pressure prevents collapse and surge initiation. The possibility of initiation must await a time of low discharge" (e.g. winter).

\section{CONGLUSIONS}

The relatively quiet Bagley Icefield surge response - in contrast to more widespread and dynamic fracturing and chaotic motion within the Bering Glacier ablation areawas accompanied by the surface stability and hence stationary-phase signal coherence necessary to obtain results from SAR interferometry. Near the Bagley Icefield/West Bagley Icefield confluence, West Bagley Icefield accelerated from January through March 1994, at an average rate of $0.5 \mathrm{~cm}$ $\mathrm{d}^{-2}$, to reach a velocity of about $1 \mathrm{~m} \mathrm{~d}^{-1}$. On Bagley Icefield, the corresponding acceleration was considerably higher at $1.3 \mathrm{~cm} \mathrm{~d}^{-2}$, with a maximum observed velocity of about $5 \mathrm{~m} \mathrm{~d}^{-1}$. For both Bagley and West Bagley these accelerations attenuated fairly linearly to near zero with distance up-glacier toward their respective flow divides. Both flow divides may have been displaced away from Bering Glacier by the surge, but this was not directly observed in the SAR data. These observations are consistent with those given by Herzfeld and Mayer (1997), who observed surge-related crevassing as far east as marker F1 in Figure 1. The segmented structure in both the velocity and acceleration profiles observed on Bagley Icefield (Fig. 2) indicates locally varying influences from longitudinal stress, bed conditions, and lateral shear stress from converging tributaries. In particular, it is likely that the lateral shear stress coupling of Bagley and West Bagley Icefields at their confluence plays an important role in modulating the velocities of each. The acceleration of
Bagley Icefield may also have constrained the flow of one of its tributaries as shown in the pre-surge to surge-state marginal shear zone analysis.

SAR images used in this study typically yielded valid data over areas of $1000-2000 \mathrm{~km}^{2}$ with a horizontal resolution of $50 \mathrm{~m}$. To analyze this large volume we have reduced the data to a small set of characteristic parameters (e.g. shear-margin widths, maximum principal strain rates, and velocity and acceleration profiles that characterize the flow and serve as an historical benchmark).

We suggest that water moving through subglacial conduits may reach and locally exceed the overburden pressure, lifting the entire ice mass several to tens of $\mathrm{cm}$ and producing frequently observed interferogram phase bull's-eyes. It is of interest to note, in light of the weak vs strong similarity of pre-surge to surge-state velocity profiles on Bagley and West Bagley Icefields, respectively, that while there is a high spatial and temporal density of bull's-eye events on Bagley Icefield, there is no evidence of phase bull's-eyes on West Bagley Icefield.

The data indicate that up to $5 \%$ of Bagley Icefield may have been influenced by bull's-eye events at any given time during the surge in winter 1994. Phase bull's-eyes with both positive and negative signs are observed, indicating surface rise and fall events per our proposed model. A large number of bull's-eyes were also observed on the post-surge stagnant ice of the Bering Glacier piedmont lobe, most of which indicate subsidence attributable to ongoing post-surge drainage of subglacial water. A similar phenomenon may have been observed in a $10 \mathrm{~cm}$ drop observed by Kamb and others (1985) using field survey techniques at the end of the 198283 surge of Variegated Glacier. On non-surging glaciers, bull's-eyes are commonly but less frequently apparent.

The phase bull's-eye model, in which pressurization/ depressurization events occur continuously along the line of maximum glacier depth, should be tested in the field by accurately monitoring surface elevations over short intervals of several days using a global positioning system network and by measuring glacier depth profiles (seismics, ice-penetrating radar). If this model proves accurate it could represent an improvement to the current picture of glacier surge dynamics.

\section{ACKNOWLEDGEMENTS}

We thank the U.S. National Science Foundation for providing initial support for this work with Small Grant for Exploratory Research OPP93-19873, NASA for providing support with grants NAGW-4930, NAG5-4068 and NAG5-8769, Cray Research, Inc. for providing additional support via their University Research and Development Grant Program, and the Arctic Region Supercomputing Center for providing computational support. We thank the Alaska SAR Facility, University of Alaska Fairbanks, for a graduate research assistantship to D. R. Fatland. We thank I. Joughin, D. Goldstein, M. A. Fahnestock, E. Rignot, W. D. Harrison, K. A. Echelmeyer, M. Truffer, C. F. Raymond and M. Nolan and our reviewers for valuable conversations and comments on this work. We also express our gratitude to R. Naruse, our editor, for his considerable assistance, encouragement and patience. 


\section{REFERENGES}

Alsdorf, D. E. and L. C. Smith. 1999. Interferometric SAR observations of ice topography and velocity changes related to the 1996, Gjálp subglacial eruption, Iceland. Int. F. Remote Sensing, 20(15-16), 3031-3050.

Bindschadler, R. 1983. The importance of pressurized subglacial water in separation and sliding at the glacier bed. F. Glaciol., 29(101), 3-19.

Clarke, G. K. C., S. G. Collins and D. E. Thompson. 1984. Flow, thermal structure, and subglacial conditions of a surge-type glacier. Can. F. Earth Sci., 21 (2), 232-240.

Fatland, D. R. 1998. Studies of Bagley Icefield during surge and Black Rapids Glacier, Alaska, using spaceborne SAR interferometry. (Ph.D. thesis, University of Alaska Fairbanks.)

Fatland, D. R. and C. S. Lingle. 1998. Analysis of the 1993-95 Bering Glacier (Alaska) surge using differential SAR interferometry. F. Glaciol., 44(148), $532-546$.

Fountain, A. G. and J. S. Walder. 1998. Water flow through temperate glaciers. Rev. Geophys., 36(3), 299-328.

Goldstein, R. M., H. Engelhardt, B. Kamb and R. M. Frolich. 1993. Satellite radar interferometry for monitoring ice sheet motion: application to an Antarctic ice stream. Science, 262(5139), 1525-1530.

Gudmundsson, G. H. 1997. Ice deformation at the confluence of two glaciers investigated with conceptual map-plane and flowline models. F. Glaciol., 43(145), 537-547.

Gudmundsson, G. H., A. Iken and M. Funk. 1997. Measurements of ice deformation at the confluence area of Unteraargletscher, Bernese Alps, Switzerland. 7. Glaciol., 43(145), 548-556.

Harper, J. T. and N. F. Humphrey. 1995. Borehole video analysis of a temperate glacier's englacial and subglacial structure: implications for glacier flow models. Geology, 23(10), 901-904.

Harrison, W. D., C. F. Raymond and P. MacKeith. 1986. Short period motion events on Variegated Glacier as observed by automatic photography and seismic methods. Ann. Glaciol., 8, 82-89.

Harrison, W. D., K. A. Echelmeyer, E. F. Chacho, C. F. Raymond and R. J. Benedict. 1994. The 1987-88 surge of West Fork Glacier, Susitna Basin, Alaska, U.S.A. 7. Glaciol., 40 (135), 241-254.

Heinrichs, T. A., L. R. Mayo, K. A. Echelmeyer and W. D. Harrison. 1996. Quiescent-phase evolution of a surge-type glacier: Black Rapids Glacier, Alaska, U.S.A. F. Glaciol., 42(140), 110-122.

Herzfeld, U. C. and H. Mayer. 1997. Surge of Bering Glacier and Bagley Ice Field, Alaska: an update to August 1995 and an interpretation of brittledeformation patterns. 7. Glaciol., 43(145), 427-434.

Hoinkes, H. C. 1969. Surges of the Vernagtferner in the Ötztal Alps since 1599. Can. 7. Earth Sci., 6(4), Part 2, 853-861.

Humphrey, N. F. and C. F. Raymond. 1994. Hydrology, erosion and sediment production in a surging glacier: Variegated Glacier, Alaska, 1982-83. 7. Glaciol., 40(136), 539-552.

Iken, A. and R. A. Bindschadler. 1986. Combined measurements of subglacial water pressure and surface velocity of Findelengletscher, Switzerland: conclusions about drainage system and sliding mechanism. f. Glaciol., 32(110), 101-119.

Iken, A., H. Röthlisberger, A. Flotron and W. Haeberli. 1983. The uplift of Unteraargletscher at the beginning of the melt season - a consequence of water storage at the bed? F. Glaciol., 29(101), 28-47.

Joughin, I.R. 1995. Estimation of ice-sheet topography and motion using interferometric synthetic aperture radar. (Ph.D. thesis, University of Washington.)

Joughin, I., R. Kwok and M. Fahnestock. 1996a. Estimation of ice-sheet motion using satellite radar interferometry: method and error analysis with application to Humboldt Glacier, Greenland. F. Glaciol., 42(142), 564-575.

Joughin, I., D. Winebrenner, M. Fahnestock, R. Kwok and W. Krabill. 1996b. Measurement of ice-sheet topography using satellite-radar interferometry. F. Glaciol., 42(140), 10-22.

Joughin, I., S. Tulaczyk, M. Fahnestock and R. Kwok. 1996c. A mini-surge on the Ryder Glacier, Greenland, observed by satellite radar interferometry. Science, 274(5285), 228-230.

Joughin, I.R., R. Kwok and M.A. Fahnestock. 1998. Interferometric estimation of three-dimensional ice-flow using ascending and descending passes. IEEE Trans. Geosci. Remote Sensing, GE-36(1), 25-37.

Joughin, I., M. Fahnestock, R. Kwok, P. Gogineni and C. Allen. 1999. Ice flow of Humboldt, Petermann and Ryder Gletscher, northern Greenland. f. Glaciol., 45 (150), 231-241.

Kamb, B. 1987. Glacier surge mechanism based on linked cavity configuration of the basal water conduit system. F. Geophys. Res., 92(B9), 9083-9100.

Kamb, B. and 7 others. 1985. Glacier surge mechanism: 1982-1983 surge of Variegated Glacier, Alaska. Science, 227(4686), 469-479.

Kwok, R. and M. A. Fahnestock. 1996. Ice sheet motion and topography from radar interferometry. IEEE Trans. Geosci. Remote Sensing, GE-34(1), 189-200.

Lingle, C. S., A. Post, U. C. Herzfeld, B. F. Molnia, R. M. Krimmel and J. J. Roush. 1993. Correspondence. Bering Glacier surge and iceberg-calving mechanism at Vitus Lake, Alaska, U.S.A. 7. Glaciol., 39(133), 722-727.

Lingle, C. S., J. J. Roush and D. R. Fatland. 1994. Time of onset of the 1993'94 surge of Bering Glacier, Alaska, and effect on iceberg calving of surge arrival at the terminus. [Abstract.] Eos, 75(44), Supplement, 64.

Molnia, B. 1993. Major surge of the Bering Glacier. Eos, 74(29), 321-322.

Molnia, B. F. and A. Post. 1995. Holocene history of Bering Glacier, Alaska: a prelude to the 1993-1994 surge. Phys. Geogr., 16(2), 87-117.

Muller, E. H. and P.J. Fleisher. 1995. Surging history and potential for renewed retreat: Bering Glacier, Alaska. Arct. Alp. Res., 27(1), 81-88.

Nolan, M. and K. Echelmeyer. 1999. Seismic detection of transient changes beneath Black Rapids Glacier, Alaska, U.S.A.: II. Basal morphology and processes. 7. Glaciol., 45(149), 132-146.

Paterson, W. S. B. 1994. The physics of glaciers. Third edition. Oxford, etc., Elsevier.

Pohjola, V. A. 1994. TV-video observations of englacial voids in Storglaciären, Sweden. 7. Glaciol., 40 (135), 231-240.

Post, A. S. 1960. The exceptional advances of the Muldrow, Black Rapids, and Susitna Glaciers. 7. Geophys. Res., 65(11), 3703-3712.

Raymond, C. F. 1987. How do glaciers surge? A review. 7. Geophys. Res., 92(B9), 9121-9134.

Reeh, N., S. N. Madsen and J.J. Mohr. 1999. Combining SAR interferometry and the equation of continuity to estimate the three-dimensional glacier surface-velocity vector. F. Glaciol., 45(151), 533-538.

Rignot, E. 1996. Tidal motion, ice velocity and melt rate of Petermann Gletscher, Greenland, measured from radar interferometry. F. Glaciol., 42(142), 476-485.

Rignot, E., K. C. Jezek and H. G. Sohn. 1995. Ice flow dynamics of the Greenland ice sheet from SAR interferometry. Geophys. Res. Lett., 22(5), 575-578.

Rignot, E., R. Forster and B. Isacks. 1996. Interferometric radar observations of Glaciar San Rafael, Chile. f. Glaciol., 42(141), 279-291. (Erratum: 42(142), p. 591.)

Robin, G. de Q. and J. Weertman. 1973. Cyclic surging of glaciers. F. Glaciol., 12(64), 3-18.

Röthlisberger, H. 1972. Water pressure in intra- and subglacial channels. $\mathcal{F}$. Glaciol., $11(62), 177-203$.

Roush, J. J. 1996. The 1993-94 surge of Bering Glacier, Alaska, observed with satellite synthetic aperture radar. (M.Sc. thesis, University of Alaska Fairbanks.)

Stenborg, T. 1970. Delay of run-off from a glacier basin. Geogr. Ann., 52A(1), 1-30.

Tangborn, W.V., R. M. Krimmel and M.F. Meier. 1975. A comparison of glacier mass balance by glaciological, hydrological and mapping methods, South Cascade Glacier, Washington. International Association of Hydrological Sciences Publication 104 (Symposium at Moscow 1971 - Snow and Ice), 185-196.

Truffer, M., W. D. Harrison and K. A. Echelmeyer. 2000. Glacier motion dominated by processses deep in underlying till. f. Glaciol., 46(153), 213-221.

Vaughan, D. G. 1993. Relating the occurrence of crevasses to surface strain rates. F. Glaciol., 39(132), 255-266. 